\title{
A simple diffusion-sedimentation model to explain planktonic gradients within a NW Mediterranean submarine cave
}

\author{
J. Garrabou, J. Flos \\ Departament d'Ecologia, Facultat de Biologia, Universitat de Barcelona, Avgda Diagonal 645, E-08028 Barcelona, Catalonia, Spain
}

\begin{abstract}
Planktonic communities dwelling inside a submarine cave in the Medes Islands (NW Mediterranean) show a steady decrease in species richness and planktonic biomass along the longitudinal axis from the entrance to the end; the lowest species and biomass values were recorded at the innermost point of the cave. This study considers the role of sedimentation in the formation of this gradient, despite previous works having demonstrated the presence of strong advection of the water inside the cave. To this end, data on planktonic density at different points within the cave at different seasons were used, leading to the developement of a simple diffusion-sedimentation model which allowed us (1) to estimate characteristic times for the formation of particle gradients; in $24 \mathrm{~h}$ of simulation or less, gradients as marked as those found in the cave were obtained; these times are in accordance with water renewal times in the cave, calculated in previous works; and (2) to simulate some planktonic (phytozooplankton) gradient profiles; significant correlations for all phytoplankton cases and some for zooplankton profiles were found. The results show that sedimentation is sufficient to explain the establishment of the planktonic gradients inside the cave.
\end{abstract}

KEY WORDS: Diffusion-sedimentation model C Caves · Plankton Gradients

\section{INTRODUCTION}

One of the most conspicuous features of submarine caves all over the world is a strong horizontal gradient in macrobenthic species richness and biomass along the axis running from outside to inside the cave (Riedl 1966, Harmelin 1969, True 1970, Gili et al. 1982, Harmelin et al. 1985, Balduzzi et al. 1989). Several authors have investigated the causes of this impoverishment (Cinelli et al. 1977, Gili et al. 1986) and have pointed to the decrease in light and advection by water as the main factors responsible for the decline observed inside the cave (Cinelli et al. 1977).

Light obviously acts on the distribution of algae in caves that open at a depth less than $50 \mathrm{~m}$ (those most frequently studied). Advection by water, jointly with other factors that are to a greater or lesser degree related to it (e.g. sedimentation, the supply of organic matter and live prey, transport by currents and the supply of larval stocks), directly affects the distribution of many benthic organisms. However, there are little experimental data clearly supporting any of the abovementioned factors.

In the cave under study, no evidence for significant advection caused by water reduction has been found (Gili et al. 1986, Zabala et al. 1989). Experiments with fluorescein (dye tracer; Zabala et al. 1989) and data from oxygen depletion (Riera et al. 1985, Zabala et al. 1989) have established a water renewal time for the cave of between 12 and $24 \mathrm{~h}$.

Study of the planktonic communities inside the Medes Islands cave, NW Mediterranean, has demonstrated the existence of strong gradients similar to those of macrobenthic communities (Palau et al. 1991). The planktonic gradient is persistent all year round; almost all the taxonomic groups that were identified in. the Medes Island cave show the same pattern of decay (phytozooplankton) except fungi, benthic diatoms and spirorbid larvae; decay values of planktonic cells along the length of the cave range between 60 and $100 \%$, while levels of such magnitude are never reached in 
open waters; hardly any meroplanktonic larvae, sponge bryozoans, etc., have been found inside the cave.

The planktonic gradients observed suggest a reduction in food supply to the macrobenthos inside the cave. The magnitude of the reduction is enough to explain macrobenthos impoverishment (Palau et al. 1991), but the cause of the plankton impoverishment gradient is not known. Palau et al. (1991) pointed out that sedimentation could be the main cause.

This study tests the hypothesis that sedimentation could be responsible for plankton impoverishment inside the cave. Previous observations had pointed out important advection movements inside the cave (Gili et al. 1986, Zabala et al, 1989). However, the mechanisms responsible for the advection movements are unknown, so they cannot be introduced into the model. The effects of advection were represented by a turbulent diffusion coefíicient, and a simple model, which included sedimentation velocity and the turbulent diffusion coefficient, was developed to test our hypothesis.

\section{MATERIALS AND METHODS}

Study cave. The cave is located in the Medes Islands (Catalonia, NW Mediterranean). It consists of a roughly cylindrical karstic hole less than $50 \mathrm{~m}$ long and 4 to $7 \mathrm{~m}$ in diameter. It opens at a depth of between 8 (upper) and $12 \mathrm{~m}$ (lower) (see Zabala et al. 1984 for a detailed topographic description) (Fig. 1).

The data used to contrast the model are derived from a previous work carried out in the cave on the structure of planktonic communities during different seasons (Palau et al. 1991). Their resulting data include organism counts for the principal phytozooplankton groups:

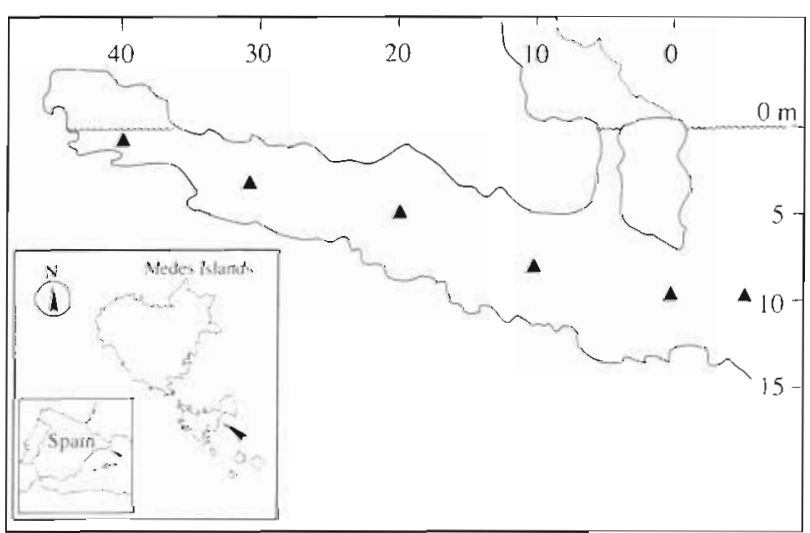

Fig. 1. Location of study cave on the island of Meda Petita, Western Mediterranean. Diagram of cave shows sampling points (
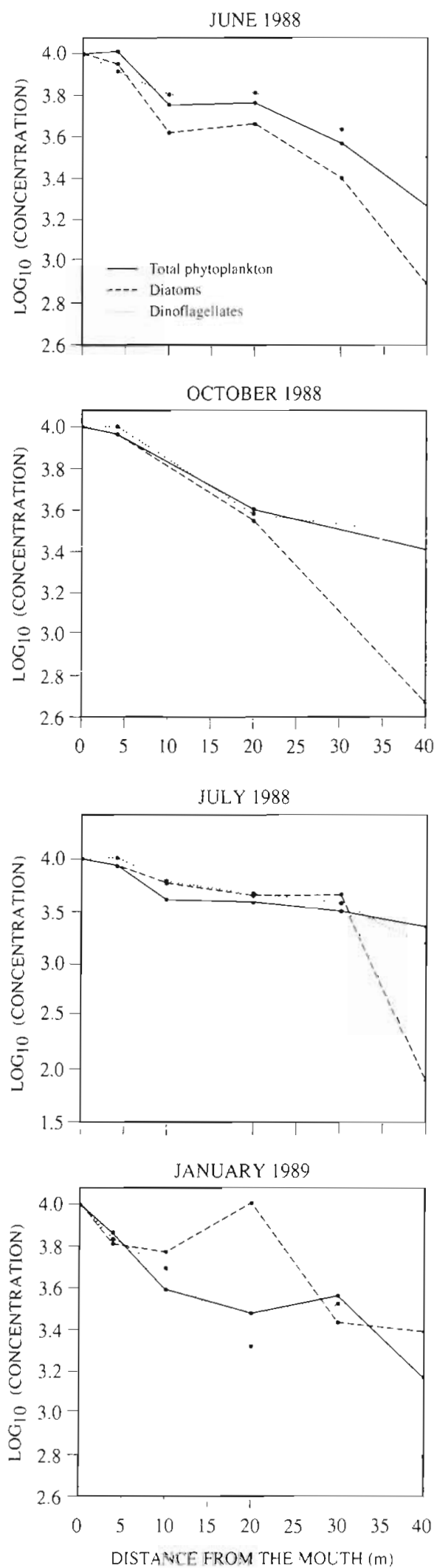

Fig. 2. Densities of phytoplankton $\left[\log _{10}\left(\mathrm{cells}_{\mathrm{cm}} \mathrm{cm}^{-3}\right)\right]$ within the cave on different sampling dates. Data from Palau et al. (1991) 
total phytoplankton, diatoms and dinoflagellates (Fig 2); total zooplankton, copepods and eggs from different taxa (Fig. 3), sampled at different points inside the cave (Fig 1) (for further information see Palau et al. 1991).

The diffusion-sedimentation model. The aim of our model is to determine whether sedimentation is enough to explain the observed planktonic gradients. Although it was assumed at first that sedimentation could be the main agent responsible for the gradients, the water renewal time of 12 to $24 \mathrm{~h}$ that has been observed (Gili et al. 1986, Zabala et al. 1989) caused us to doubt the validity of this simple physical explanation. We thus attempted to demonstrate whether the flow features observed, together with the rates of sedimentation known for the planktonic particles, were compatible with the gradients observed.

The experiments with fluorescein (in which various sections were sampled, the samples in each one being taken from the axis to the walls, throughout the length of the cave) showed a highly complex global pattern, with apparently variable and irregular diffusion in space and time. These results, fast water renewal time and complex circulation patterns, suggested that there is some mechanism introducing turbulent mixing into the cave. The available data only permit conclusions about a turbulent diffusion coefficient, $K$, but do not reveal the magnitude and direction of the velocity vector field. Hydrodynamic theory would suggest that mean flow fields are involved in the process, yet cannot be handled due to lack of measurements. However, to find out whether sedimentation can explain observed planktonic gradients, it was sufficient to work on the basis of a model that did not contain terms for either advection or shear, and in which only 1 parameter of turbulent diffusion (the turbulent diffusion coefficient, $K$ ) was contemplated.

The model is based on 2 dimensions ( $x$ for horizontal direction, $z$ for vertical direction). The concentration $C$ $(x, z, t)$ of plankton particles at position $(x, z)$ at different times $(t)$ is governed by the following equation (Okubo 1980):

$$
\frac{\partial C}{\partial t}-w_{\mathrm{s}} \frac{\partial C}{\partial z}=K\left(\frac{\partial^{2} C}{\partial x^{2}}+\frac{\partial^{2} C}{\partial z^{2}}\right)
$$

(a)

(b)

(c)

where term (a) represents the rate of change with time (t) of plankton particles at a given point. Term (b) is vertical advection, where $w_{\mathrm{s}}$ is plankton particle sedimentation velocity. It is assumed that horizontal fluxes are all due to eddy diffusion. Plankton particles are dispersed in 2 dimensions, horizontal and vertical, by the turbulent diffusion (term c) with the constant turbulent coefficient $(K)$, which is assumed to be equal in both directions ( $x$ and $z$ ).
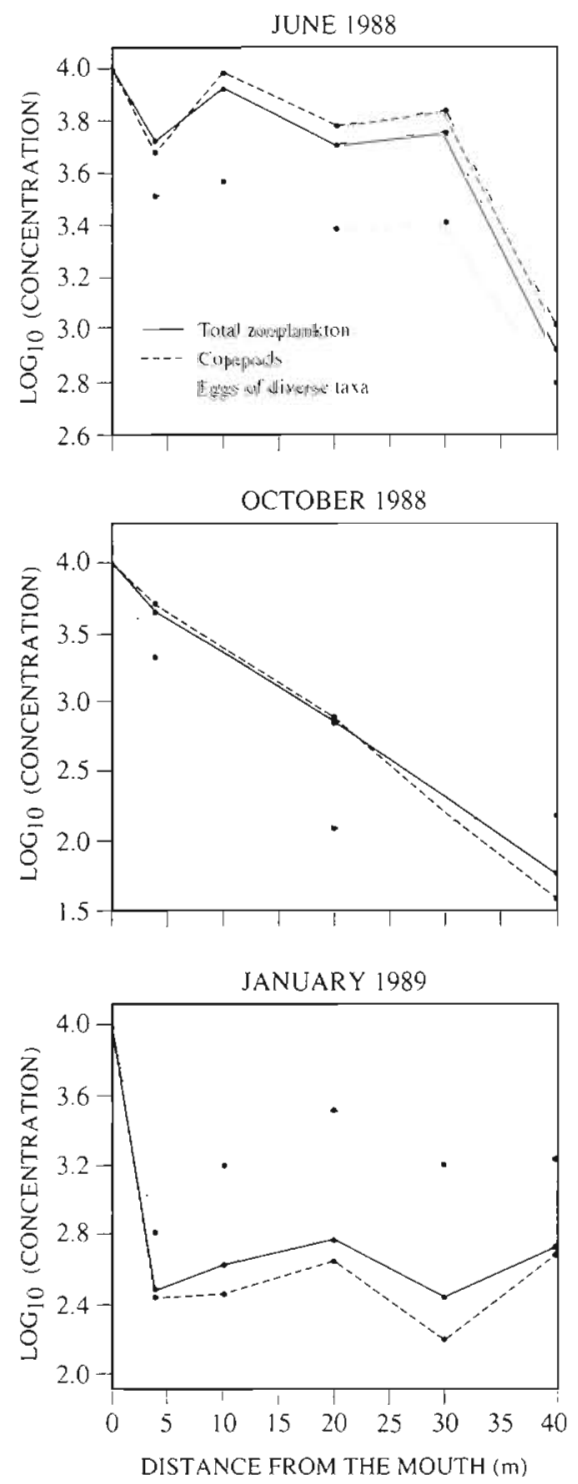

Fig. 3. Densities of zooplankton $\left[\log _{10}\left(\right.\right.$ ind $\left.\left.\mathrm{m}^{-3}\right)\right]$ within the cave on different sampling dates. Data from Palau et al. (1991)

The model (Eq. 1) considers 2 dimensions ( $x$ and $z$ ), which do not provide information about variations in the horizontal cross, direction $y$. Concentrations should be regarded as $y$-averaged. Taking into account the size of the cave (no greater than $5 \mathrm{~m}$ in direction $y$ ) and its shape, this simplification does not have any effect on the proposed model.

This model was numerically solved using the centred differences method (see 'Appendix'). Calculations were carried out on a $12 \times 43$ cell grid $(1 \times 1 \mathrm{~m})$, assuming the following boundary conditions (Fig. 1): a null flux boundary in the upper section of the grid and unidirectional flux in its lower section (sink to the bottom) without resuspension. As a consequence, the concen- 
tration-change integration of plankton particles follows the geometry of the cave.

Estimations of turbulent diffusion (K) values: None of the experiments (fluorescein tracer and oxygen depletion) carried out to determine the water renewal time in the cave (Gili et al. 1986, Zabala et al. 1989) made a direct estimate of the turbulent diffusion coefficient $(K)$ inside it. To estimate its values the tracer experiments were simulated using Eq. (2), solved in the same way (grid, numerical method, boundary conditions, etc.) as the diffusion-sedimentation model (Okubo 1980).

$$
\frac{\partial C}{\partial t}=K\left(\frac{\partial^{2} C}{\partial x^{2}}+\frac{\partial^{2} C}{\partial z^{2}}\right)-d C
$$

This equation describes the tracer (fluorescein and oxygen) concentrations ( $C$ ) that are dispersed in 2 dimensions, the horizontal $(x)$ and vertical $(z)$ dimension, by turbulent diffusion with constant coefficient $K$. The last term represents the local reduction of concentration due to the depletion of the tracer (oxygen) at the instantaneous depletion rate (d).

The obtained values which were compatible with the water renewal time found in the cave were used for simulation with the model.

Simulation of the fluorescein experiments: The results of 2 experiments carried out in the cave are detailed in Zabala et al. (1989). They consisted of injecting fluorescein at the entrance and at the end of the cave. In both cases observations of the concentration change of the tracer at different fixed spots in the cave were made. Fluorescein could be detected everywhere (in no uniform concentrations) only 40 min after the injection, and all trace of the signal was lost between 6 and $12 \mathrm{~h}$ after the onset of the experiments. The authors of the experiments did not report absolute values for the tracer concentration.

Assuming that $C(x, z, 0)=0$ in the whole cave, except for an innermost cell and without any depletion $(d=0)$, calculations were made to find out how long it would take for the concentration of fluorescein at the end of the cave to decrease to 50 , to 10 and to $1 \%$. Diffusion coefficients $(K)$ ranging from 0.01 to $0.1 \mathrm{~m}^{2} \mathrm{~s}^{-1}$ (Fig. 4) are needed to make the tracer concentration become undetectable in 12 to 6 h respectively.

Simulation of the oxygen depletion: The average oxygen depletion rate in the cave varies from a maximum of 0.09 to a minimum of $0.06 \mathrm{mg} \mathrm{O} \mathrm{O}_{2} \mathrm{l}^{-1} \mathrm{~h}^{-1}$. These depletion estimates consider the biological oxygen demand (BOD) of the water column, benthic organisms inside the cave, sediment and a population of the cave-dwelling mysid Hemimysis speluncola. The number of mysids varies during the year between a minimum of 1 million in winter and a maximum of 15 million in spring (M. Ribes, R. Coma \& $M$. Zabala unpubl.). Mysid oxygen consumption was cal-

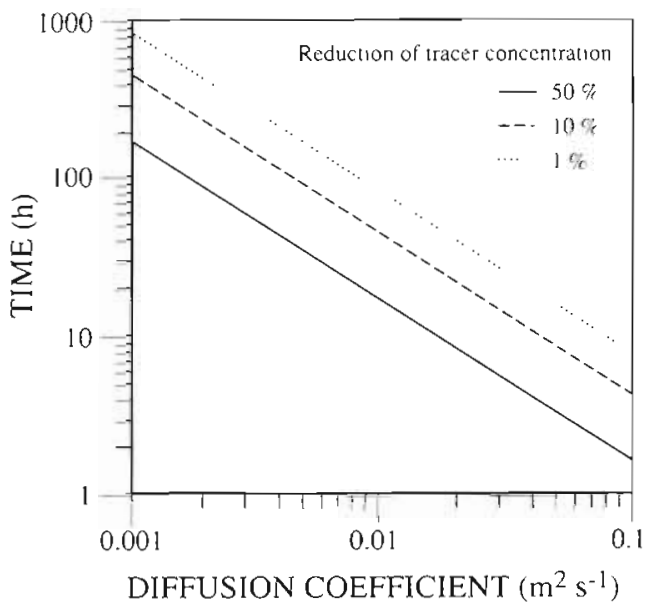

Fig. 4. Time necessary to reduce tracer concentration to 50 , 10 , and $1 \%$ of initial concentration value for different diffusion coefficents

culated from allometric functions (Peters 1983), which could represent half the total oxygen deplction of the cave.

The oxygen concentration inside the cave is affected by the processes above. The difference in oxygen concentration, inside and outside the cave, varied between 0.17 and $1.09 \mathrm{mg} \mathrm{O}_{2} \mathrm{I}^{-1}$.

The maximum and minimum depletion rates $(d)=$ constant) were simulated, assuming a uniform concentration of $10 \mathrm{mg} \mathrm{O}_{2} \mathrm{l}^{-1}$ inside the cave at $t=0$ and keeping this concentration constant throughout the simulation at the entrance. The time necessary to achieve the average difference observed, $0.6 \mathrm{mg} \mathrm{O} \mathrm{O}_{2} \mathrm{l}^{-1}$, was calculated for different values of the turbulent diffusion coefficient.

For turbulent diffusion coefficients lower than $10^{-1} \mathrm{~m}^{2} \mathrm{~s}^{-1}$, a difference of $0.6 \mathrm{mg} \mathrm{O}_{2} \mathrm{l}^{-1}$ was reached in less than $24 \mathrm{~h}$ (Fig. 5), while for $K=10^{-1} \mathrm{~m}^{2} \mathrm{~s}^{-1}$ the differences attained were lower than $0.6 \mathrm{mg} \mathrm{O}_{2} \mathrm{l}^{-1}$. Such values had been observed in the cave too $10.17 \mathrm{mg} \mathrm{O}_{2}$ $1^{-1}$; Riera et al, 1985)

The estimated values for $K$, obtained from the simulations of the experiments with Eq. (2), ranged between $10^{-3}$ and $10^{-1} \mathrm{~m}^{2} \mathrm{~s}^{-1}$

Plankton sedimentation velocities $\left(w_{s}\right)$ : The sedimentation velocities characteristic for the phytoplankton varied between $10^{-7}$ and $10^{-3} \mathrm{~m} \mathrm{~s}^{-1}$ (Smayda 1970). Zooplankton was considered to act as passive particles with sedimentation velocities among the highest known for phytoplankton. But it is known that many zooplankton species have the ability to swim vertically at speeds ranging from $10^{-4}$ to $10^{-2} \mathrm{~m} \mathrm{~s}^{-1}$ (Levinton 1982) and horizontally from 0.04 to $0.18 \mathrm{~m} \mathrm{~s}^{-1}$ (Shanks 1985). Should these speeds remain steady in time and direction, and apply to the cave species as well, the 


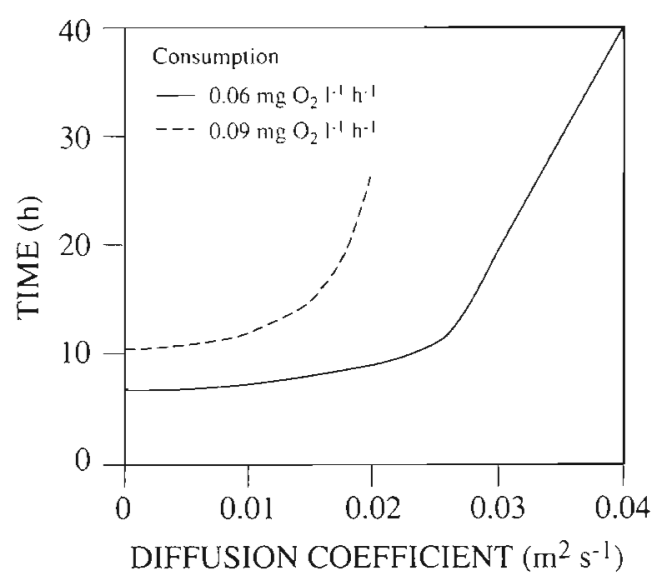

Fig. 5. Time necessary to reach a difference in oxygen concentration of $0.6 \mathrm{mg} \mathrm{O}_{2} \mathrm{l}^{-1}$ between the entrance and the end of the cave

model would no longer be valid as plankton particles could not be regarded as passive elements. This is not the case with most phytoplankton species.

\section{RESULTS}

\section{Standard periods required to fill and empty the cave}

With the turbulent diffusion coefficients estimated above and sedimentation velocities $\left(w_{\mathrm{s}}\right)$ characteristic of the phytoplankton (between $10^{-6}$ and $10^{-4} \mathrm{~m} \mathrm{~s}^{-1}$; Smayda 1970), several simulations of plankton particles going in and out of the cave were carried out on the basis of model 1 (Eq. 1) to establish the range of times required to fill the cave with particles and to empty it.

\section{Filling the cave with particles}

For these simulations it was considered that the concentration inside the cave was, at first, zero, whereas at the entrance it was not zero and that it remained constant throughout the simulation. The particle concentration at the end of the cave was calculated after $24 \mathrm{~h}$ of simulation (the standard water renewal time). Three values of the turbulent diffusion coefficent $(K)$ were used with different sedimentation velocities.

In less than $24 \mathrm{~h}$ with $K$ equal to $10^{-1} \mathrm{~m}^{2} \mathrm{~s}^{-1}$ and $w_{\mathrm{s}}$ between $10^{-6}$ and $10^{-4} \mathrm{~m} \mathrm{~s}^{-1}$, the particle concentration reached in the innermost part of the cave varied from 99.8 to $87.8 \%$ of the concentration at the entrance. For lower values of $K$, the concentration attained at the end of the cave did not exceed $67.4 \%$ of the concentration at the entrance (Fig. 6).

\section{Emptying the cave of particles}

In these simulations it was assumed that the cave was, at first, full of particles and the concentration was maintained constant and equal to the initial value at the entrance throughout the simulation. The concentration of particles at the end of the cave was calculated after $24 \mathrm{~h}$ of simulation. The $K$ and $w_{\mathrm{s}}$ values used above were also used in these simulations.

The results showed that the lower the value of $K$ with the same $W_{s}$, the greater the particle concentration gradient achieved. With $K$ lower than $10^{-2} \mathrm{~m}^{2} \mathrm{~s}^{-1}$ and $w_{\mathrm{s}}$ greater than or equal to $10^{-5} \mathrm{~m} \mathrm{~s}^{-1}$, particle concentration decay levels at the end of the cave ranged between 100 and $10 \%$ (Fig. 6), similar to gradient values observed in the cave.
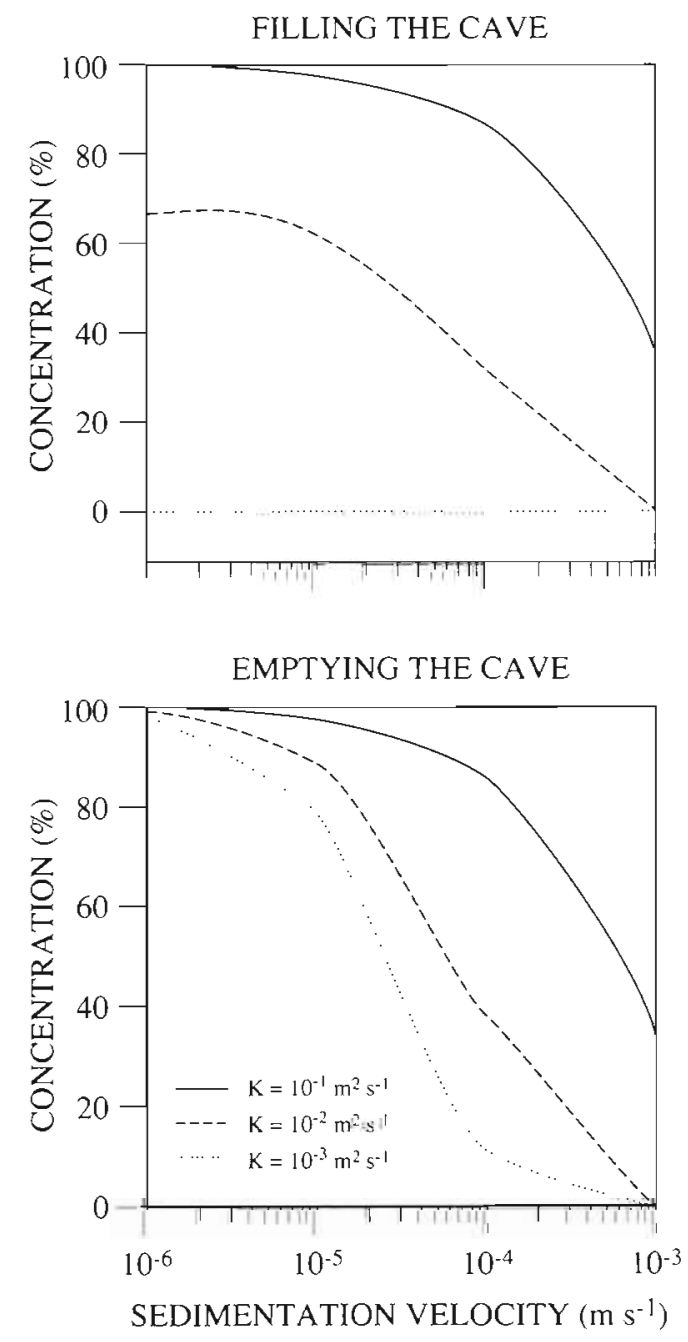

Fig. 6. Simulation results of filling and emptying the cave. Concentration at the end of the cave after $24 \mathrm{~h}$ of simulation with different turbulent diffusion coefficient values $(K)$ and sedimentation velocities 
For values of $K$ lower than or equal to $10^{-2} \mathrm{~m}^{2} \mathrm{~s}^{-1}$ and $w_{\mathrm{s}}$ greater than or equal to $10^{-5} \mathrm{~m} \mathrm{~s}^{-1}$, the cave was emptied of particles in less than $24 \mathrm{~h}$.

\section{Experimental plankton profile simulation}

An expression representing the steady state of the model can be obtained by equating term (a) from Eq. (1) to 0 and dividing by $K$. It should be noted that each steady state then depends on the ratio $w_{\mathrm{s}} / K$. Equal values of the ratio from different combinations of $w_{\mathrm{s}}$ and $K$ simulate the same steady state.

The steady states corresponding to a range of values of $w_{\mathrm{s}} / K$ were simulated (Fig. 7). From these data it was possible to establish concentration gradients versus distance from the entrance of the cave. Using these 2 values, $w_{\mathrm{s}} / K$ and the concentration gradient (slope of $C$ vs $x, x$ being the distance to the mouth), a relationship was established using the principal axis approach (Sokal \& Rohlf 1969). This relationship makes it possible to interpolate these quotients $w_{\mathrm{s}} / K$ from experimental data of gradients

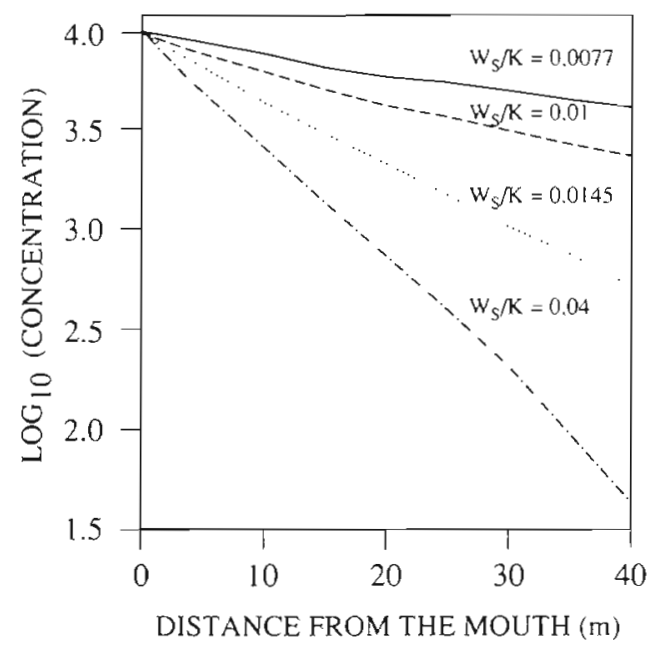

Fig. 7. Some steady states derived from simulations with the model for different vaiues of $w_{\mathrm{s}} / K$

of concentration versus distance from the cave entrance (assuming that the resulting distribution corresponded to a steady state). When $w_{\mathrm{s}} / K$ are inter-

Table 1. Correlations between planktonic densities from real and simulated data with the model (r: correlation coefficient; significance levels: $p<0.5, \cdots p<0.01, \cdots p<0.001$, ns: not significant), and estimates of the turbulent diffusion coefficient from real data (for sedimentation rates $w_{\mathrm{s}} 1=10^{-6}$ and $w_{\mathrm{s}} 2=10^{-4} \mathrm{~m} \mathrm{~s}^{-1}$ )

\begin{tabular}{|c|c|c|c|c|c|}
\hline Date of sampling & Planktonic taxa & $r$ & $\mathrm{p}$ & $\begin{array}{l}\text { Estimated coeffic } \\
\qquad w_{\mathrm{s}} 1\end{array}$ & $\begin{array}{l}\text { rbulent diffusion } \\
\quad w_{\mathrm{s}} 2\end{array}$ \\
\hline \multirow[t]{6}{*}{ June 1988} & Total phytoplankton & 0.96 & $\because$ & $5.15 \times 10^{-5}$ & $5.15 \times 10^{-3}$ \\
\hline & Diatoms & 0.94 & $\cdot \cdot$ & $3.58 \times 10^{-5}$ & $3.58 \times 10^{-3}$ \\
\hline & Dinoflagellates & 0.96 & $\because$ & $8.76 \times 10^{-5}$ & $8.76 \times 10^{-3}$ \\
\hline & Total zooplankton & 0.78 & $\cdot$ & - & - \\
\hline & Copepods & 0.71 & ns & - & - \\
\hline & Eggs & 0.88 & *. & - & - \\
\hline \multirow[t]{3}{*}{ July 1988} & Total phytoplankton & 0.94 & $\cdots$ & $5.80 \times 10^{-5}$ & $5.80 \times 10^{-3}$ \\
\hline & Diatoms & 0.82 & $\cdots$ & $1.98 \times 10^{-5}$ & $1.98 \times 10^{-3}$ \\
\hline & Dinoflagellates & 0.96 & $\cdot \cdot$ & $4.76 \times 10^{-5}$ & $4.76 \times 10^{-3}$ \\
\hline \multirow[t]{6}{*}{ October 1988} & Total phytoplankton & 0.98 & $\cdots$ & $6.48 \times 10^{-5}$ & $6.48 \times 10^{-3}$ \\
\hline & Diatoms & 0.98 & $\cdot \cdot$ & $2.62 \times 10^{-5}$ & $2.62 \times 10^{-3}$ \\
\hline & Dinoflagellates & 0.94 & $\cdot$ & $7.26 \times 10^{-5}$ & $7.26 \times 10^{-3}$ \\
\hline & Total zooplankton & 0.99 & $\cdots$ & - & - \\
\hline & Copepods & 0.99 & $\cdots$ & - & - \\
\hline & Eggs & 0.84 & ns & - & - \\
\hline \multirow[t]{6}{*}{ January 1989} & Total phytoplankton & 0.93 & $\because$ & $5.24 \times 10^{-5}$ & $5.24 \times 10^{-3}$ \\
\hline & Diatoms & 0.77 & $\cdot$ & $6.89 \times 10^{-5}$ & $6.89 \times 10^{-3}$ \\
\hline & Dinoflagellates & 0.92 & $\cdot \cdot$ & $3.39 \times 10^{-5}$ & $3.39 \times 10^{-3}$ \\
\hline & Total zooplankton & 0.50 & $\mathrm{~ns}$ & - & - \\
\hline & Copepods & 0.51 & ns & - & - \\
\hline & Eggs & - & - & - & - \\
\hline
\end{tabular}


polated, it is possible to simulate each experimental profile and to achieve the corresponding steady state value.

In contrast to simulated profiles, most experimental profiles are not in a steady state; compare profiles in a typical steady state (Fig. 7) with experimental data (Figs. 2 \& 3). Yet most of them appear to tend to decrease towards the inner part of the cave, which, in many cases, establishes significant correlations between the gradient of plankton concentrations found by Palau et al. (1991) and those obtained from the corresponding simulations as shown in Table 1.

Using the $w_{\mathrm{s}} / K$ quotients estimated for phytoplankton and the $w_{\mathrm{s}}$ values obtained from the literature, the $K$ corresponding to each case (Table 1 ) can be calculated. The estimated $K$ value varies from $8 \times 10^{-3}$ to $2 \times 10^{-5} \mathrm{~m}^{2} \mathrm{~s}^{-1}$ for the highest and lowest values of $w_{\mathrm{s}}$ used, respectively.

\section{DISCUSSION}

The estimates of $K$ obtained from the simulation of fluorescein experiments and oxygen depletion range between $10^{-3}$ and $10^{-1} \mathrm{~m}^{2} \mathrm{~s}^{-1}$. A third estimate, derived from simulations of the phytoplankton experimental profiles, partially corroborates this range of variation. We must bear in mind, though, that steady-state-like plankton profiles used for these estimations should correspond to the lower part of the range for $K$.

Most of the data used to estimate $K$ were obtained in calm weather conditions. The simulations with these $K$ values showed that water renewal times fell between 12 and $24 \mathrm{~h}$. This suggests that there is a strong physical mechanism responsible for the water renewal inside the cave, which is probably reinforced during rough weather. Unfortunately, with the data set available it is not possible to determine this.

Among the different factors that can determine the distribution of planktonic communities throughout the cave, the sedimentation velocity of plankton particles $\left(w_{s}\right)$ and the advective transport that we have parameterized here by means of $K$ are the most important. The grazing inside the cave under study seems irrelevant because: (1) the large population of mysids feeds outside the cave (Riera et al 1991): (2) predation by planktonic consumers is unlikely to be important because all planktonic groups, prey and predator, disappear at the same time (Palau et al. 1991); (3) although consumption rates from suspension feeders (sponges, scleractinians etc.) are lacking for the cave, it is not likely that they produce an important planktonic depletion (Palau et al. 1991); and (4) other cavedwelling organisms like the fish Anthias anthias, frequently found in the inner part of the cave, have been observed feeding on mysids but not on other planktonic groups (authors' pers. obs.). $w_{\mathrm{s}}$ is unique for each species and their physiological state (Smayda 1970). and in our model it can be considered to have a constant value considering the short water renewal time of the cave (Smayda \& Mitchell-Innes 1974), whereas $K$ is variable, depending on the hydrodynamic conditions. So, when hydrodynamic activities are high ( $K$ higher than $\left.10^{-1} \mathrm{~m}^{2} \mathrm{~s}^{-1}\right)$, diffusion can, in a few hours, replenish the number of particles lost by sedimentation inside the cave. At this stage, the gradient between the inside and the outside of the cave is at minimum. This stage was never sampled. When hydrodynamic activities decrease ( $K$ lower than $10^{-1} \mathrm{~m}^{2} \mathrm{~s}^{-1}$ ), diffusion does not bring in as many particles as those lost by sedimentation. This becomes more evident when the distance between inside and outside locations of the cave increases, leading to the creation of gradients that were actually observed after a few hours.

This is obviously a simplification, given the fact that neither plankton concentration nor $K$ (as already pointed out) are constant in time, which causes irregularities in the gradients being formed. The profiles discovered by Palau et al. (1991) are juxtapositions of different $K$ stages and different plankton concentrations in the water outside the cave. The irregular patterns of some observed gradients were successfully simulated by the model when selecting variable values of concentration outside the cave and of $K$ (graphics not shown). When the loss of plankton particles inside the cave increases, i.e. when diffusion coefficient values are low, some zooplankton groups can, given their swimming ability, flee or gather at any point of the cave. This explains why the observed profiles of zooplankton are generally more erratic than those of phytoplankton and the correlations with the calculations are not as good as for phytoplankton.

The main conclusion resulting from the model is that, even with moderately high flow and flushing activities, sedimentation is sufficient to explain the plankton gradients observed in the cave.

If data for planktonic density, particulate matter and flow characteristics were obtained for other caves, our model could easily be extended to them. The only available data set on sedimentation rates in a cave near Marseilles, France (Fichez 1989), suggests the existence of steep gradients resembling those found by Palau et al. (1991).

Acknowledgements. We thank Prof. Ángel Villarroya for the unconditional help he offered during the model planning. We also thank Prof. Emilio Garcia for his critical reviews and comments which helped to improve and clarify the manuscript. Finally we thank Prof. J. M. Gili for his helpful suggestions on the manuscript. 


\section{APPENDIX}

The model was solved numerically by the centred differences method; see the following equations (Noye 1987)

$$
\begin{aligned}
& C_{x}^{t+\Delta t}(j, j)=\frac{\Delta t}{\Delta x} \frac{K}{\Delta x}\left[2 C^{t}(i, j)+C^{t}(i, j+1)-C^{\prime}(i, j-1)\right] \\
& C_{z}^{i-\Delta t}=\frac{\Delta t}{\Delta z}\left\{w \frac{C^{t}(i-1, j)-C^{\prime}(i+1, j)}{2}+\frac{K}{\Delta z}\left[2 C^{\prime}(i, j)+C^{\prime}(i+1, j)-C^{t}(j-1, j)\right]\right\} \\
& C^{i+\Delta t}(i, j)=C_{x}^{i+\Delta t}(i, j)+C_{z}^{i-\Delta i}(i, j)+C^{t}(i, j)
\end{aligned}
$$

where $C(i, j)$ is the particle concentration at grid point $(i, j), C(i+1, j)$ is the concentration at $1 \mathrm{~m}$ to the right of point $(i, j)$ and so on. $K$ is turbulent diffusion, $w_{\mathrm{s}}$ is sedimentation velocity, and $\Delta t$ is time step of simulation.

Eqs. (A1) and (A2) express the changes in the particle concentration throughout the time in the $x$ and $z$ directions respectively, while Eq. (A3) expresses the total change in particle concentration at any point $(i, j)$ inside the cave.

The following boundary conditions were used: a null flux boundary in the upper section of the grid and a unidirectional flux in its lower section (sink to the bottom) without resuspension. Then, the concentration-change integration of plankton particles follows the geometry of the cave.

To test whether this numerical method used introduces turbulent diffusion in the solution of our model, analytical (Eq. A4) and numerical solutions for a rectangular grid large enough to avoid edge effects and without sedimeniation ( $W_{\mathrm{s}}=0$ ) in Eq. (1) were compared.

$$
C(x, z, t)=\frac{C_{0}}{4 K t} \exp \left[-\frac{\left(x-x_{p}\right)^{2}+\left(z-z_{p}\right)^{2}}{4 K t}\right]
$$

The numerical and analytical resolutions consider at $t=0$ a concentration of particles to be zero everywhere except at point $\left(x_{p}, z_{p}\right)$; the concentration at that point is the value of $C_{0}$.

The 2 solutions show no significant differences.

\section{LITERATURE CITED}

Balduzzi A, Bianchi F, Boero F, Cattaneo Vietti R, Pansini M, Sarà M (1989) Topics in marine biology. Scientia mar 53(2-3):387-395

Cinelli F, Fresi E, Mazzella L, Pansini M, Pronzato R, Svoboda A (1977) Distribution of benthic phyto- and zoocoenoses along a light gradient in superficial marine cave. In: Keegan BF, O'Céidigh PO, Boaden PJS (eds) Biology of benthic organisms. Pergamon Press, Oxford, p 173-183

Fichez R (1989) Conditions d'oligotrophie en milieu aphotique, étude des grottes sous-marines, comparaison avec les milieux profonds et bilans énergétiques. $\mathrm{PhD}$ thesis, University Aix-Marseille II

Gili JM, Olivella I, Zabala M, Ros J (1982) Primera contribución al conocimiento del poblamiento bentónico de las cuevas submarinas del litoral catalán. Actas ler Simp Ibér Estudios mar 2:813-836

Gili JM, Riera T, Zabala M (1986) Physical and biological gradients in a submarine cave on the Western Mediterranean coast (north-east Spain). Mar Biol 90:291-297

Harmelin JG (1969) Bryozoaires des grottes sous-marines obscures de la région marseillasse, faunistique et écologie. Téthys 1:793-806

Harmelin JG, Vacelet J, Vasseur P (1985) Les grottes sousmarines obscures: un milieu extrême et remarquable biotope réfuge. Téthys $11(3-4): 214-229$

Levinton JS (1982) Marine ecology. Prentice-Hall, Englewood Cliffs, $N J$

Noye J (1987) Finite difference methods for solving the onedimensional transport equation. In: Noye J (ed) Numerical modelling: applications to marine systems. Elsevier Science Publishers, Amsterdam

Okubo A (1980) Diffusion and ecological problems: mathe- matical models. Biomathematics Series 10, Springer Verlag, Berlin

Palau M, Cornet C, Riera T, Zabala M (1991) Planktonic gradients along a Mediterranean sea cave. Oecol aquat 10 : 299-316

Peters RH (1983) The ecological implications of body size. Cambridge University Press, Cambridge

Riedl R (1966) Biologie der Meereshöhlen. Paul Parey, Hamburg

Riera T, Gili JM, Zabala M (1985) Respiration, teneur en oxygène et renouvelement de l'eau dans une grotte sousmarine. Rapp Comm int Mer Médit 29(5):163-166

Riera T, Zabala M, Peñuelas J (1991) Mysids from a submarine cave emerge each night to feed. Scientia mar 55(4): $605-609$

Shanks AL (1985) Behavioural basis of internal-wave induced shoreward transport of megalopae of the crab Pachygrapsus crassipes. Mar Ecol Prog Ser 24:289-295

Smayda TJ (1970) The suspension and sinking of phytoplankton in the sea. Oceanogr mar biol A rev 8:353-414

Smayda TJ, Mitchell-Inness B (1974) Dark survival of autotrophic planktonic marine diatoms. Mar Biol 25:195-202

Sokal RS, Rohlf FJ (1969) Biometry. Freeman, New York

True MA (1970) Etude quantitative de quatre peuplements sciaphiles sur substrat rocheux dans la région marseillaise. Bull Inst océanogr Monaco 69(1401):1-48

Zabala M. Gili JM, Riera T, Huelin MF (1984) Estudio de los factores fisicos y biológicos de una cueva submarina del litoral catalán. I: Metodología y primeros resultados. Acta 4er Simp Ibér Estudıos Bentos mar 1:1.09-121

Zabala M, Riera T, Gili JM, Barange $M$, Lobo A, Penuelas J (1989) Water flow, trophic depletion, and benthic macrofauna impoverishment in a submarine cave from the western Mediterranean. PSZN I: Mar Ecol 10(3):271-287 